\title{
Aquatic silk proteins in Chironomus: A review
}

\author{
Leena J. THORAT,* Bimalendu B. NATH* \\ Stress Biology Research Laboratory, Department of Zoology, Savitribai Phule Pune University, Pune-411007, India \\ Corresponding authors: leenathorat@gmail.com; bbnath@gmail.com
}

\begin{abstract}
Silk proteins secreted by salivary glands in the dipteran insect, Chironomus play a significant role as proteinaceous adhesives for construction of underwater housing nests by larvae. To date, only three Chironomus species, C. tentans Fabricius, $C$. pallidivittatus Malloch and C. riparius Meigen have been explored for characterization of their aquatic silk protein. Genes coding for silk proteins are located on specific chromosomal 'puffs' called Balbiani rings as well as non-Balbiani ring regions. Expression of these genes is closely regulated by developmental and hormonal alterations and environmental factors. Furthermore, pilot studies have postulated that silk proteins probably occur in diverse size classes grouped into large ( 1000 kDa), intermediate (100-200 $\mathrm{kDa})$ and small $(\leq 100 \mathrm{kDa})$. Barring few preliminary reports that date back to the $1990 \mathrm{~s}$, the physical and bioproperties of silk from chironomid midges remain largely unknown, leading to paucity of updated information. This review was therefore aimed to compile existing literature database and to highlight the wide possibilities for commercialization of midge larval silk as a novel biopolymer.
\end{abstract}

Key words: Chironomus; midge; aquatic silk protein; salivary glands; Balbiani ring; biological adhesive; biopolymer.

Received: February 2018. Accepted: July 2018.

This paper was presented at the 20 $0^{\text {th }}$ International Symposium on Chironomidae, Trento, Italy, 2-8 July 2017. Session: Autecology and Physiology.

\section{INTRODUCTION}

Nature is home to a vast repertoire of natural adhesives synthesized by biological systems that serve as a holdfast or tethering device to facilitate body attachment to a surface or to another organism during copulation or parasitism (Flammang and Santos, 2015). Thus, depending on function, biological adhesive structures not only exhibit unique patterns with complex and impeccable spatial dimensions but also differ in their nature and composition. Such a diverse variety of natural adhesives has greatly influenced the field of bioadhesion research, which aims to mimic the production of environment friendly, biocompatible and reliable materials with robust designs for commercial and biomedical applications (Graham, 2008; Smith, 2016). One such remarkable example of animal bioadhesives is silk produced by a number of animals including mussels, insects and spiders (Jin and Kaplan, 2003; Hardy et al., 2008; Sone, 2016; Andersson et al., 2016; Forooshani and Lee, 2017; Aigner et al., 2018). Although silkworms and spiders remain the oldest known and the most extensively studied silk-producing arthropods, growing research in this field has added several other insects to this list viz. honeybees, crickets, ants, hornets, lacewings, silverfish, caddis flies and chironomid midges (Weisman et al., 2008; Sehnal and Sutherland, 2008; Sutherland et al. 2010; Walker et al., 2012; Sutherland et al., 2011). In the purview of aquatic silks spun underwater, the retreat maker caddisworms (Stewart and Wang 2010; Tsukada et al., 2010; Ohkawa et al., 2014; Ashton et al., 2016) and larval chironomid midges (Grossbach, 1977; Hertner et al., 1980; Wellman and Case, 1989; Case et al., 1994) have exhibited how habitats influence the nature, composition and properties of silk. This review focusses on the underexplored silk-spinning expertise and the little known physiological biochemistry of silk protein produced by Chironomus larvae.

Silks are referred to as extra-organismal proteinaceous secretions (Sehnal and Akai 1990). Phylogenetic analyses have suggested that the ability to produce silk proteins has evolved multiple times in arthropods and that silk proteins represent particular animal behaviour that may potentially influence molecular properties of the protein in question (Craig, 1997). Recently, Sutherland et al. (2006) described a pathway for the evolution of silk genes in honey bees, while Yonemura et al. (2006) demonstrated homology between trichopteran silk from aquatic caddis fly larvae with lepidopteran silk. Underwater silk-woven housing nests in Chironomus is a result of the tubicolous nature of larval midges and has often been associated with its remarkable resilience to a variety of environmental stressors, especially drought-induced photo-oxidative damage (Watanabe et al., 2004; Watanabe, 2006; Thorat and Nath, 2015; Thorat and Nath, 2016; Thorat et al., 
2017). Data from our laboratory has indicated that the housing nests built by $C$. ramosus measure $1.58 \pm 0.2 \mathrm{~cm}$ in length (Fig. 1). Interestingly, Chironomus larvae were shown to recognise their self-built tubes, a behaviour speculated to involve the role of cuticular pheromones (Nath and Raut, 1998; Naik et al., 2006). One of the earliest reports on the silk-spinning machinery of chironomid larvae came from Churney (1940) and Case and Daneholt (1977), which generated considerable interest and provided a preliminary basis of midge silk with respect to its physiological biochemistry and molecular composition. Till date, silk protein from only three Chironomus species, namely, C. tentans Fabricius, C. pallidivittatus Malloch and C. riparius Meigen has been studied. Among these, $C$. tentans is most extensively documented, last report of which appeared in the late 1990s. Thus, there is a huge gap of updated information for almost two decades and as a result, our current knowledge in this premise is rather fragmentary. Therefore, the aim of this review was collation of existing literature and presentation of the little-known scenario in this subject followed by an overall view of the extensive possibilities of bioprospecting and commercial exploitation of midge larval silk as a novel biopolymer.

\section{CHIRONOMID BIOLOGY: BRIEF OVERVIEW}

Chironomid midges are dipteran insects (family Chironomidae; genus Chironomus) that inhabit freshwater bodies, temporary rock pools, wetlands and terrestrial

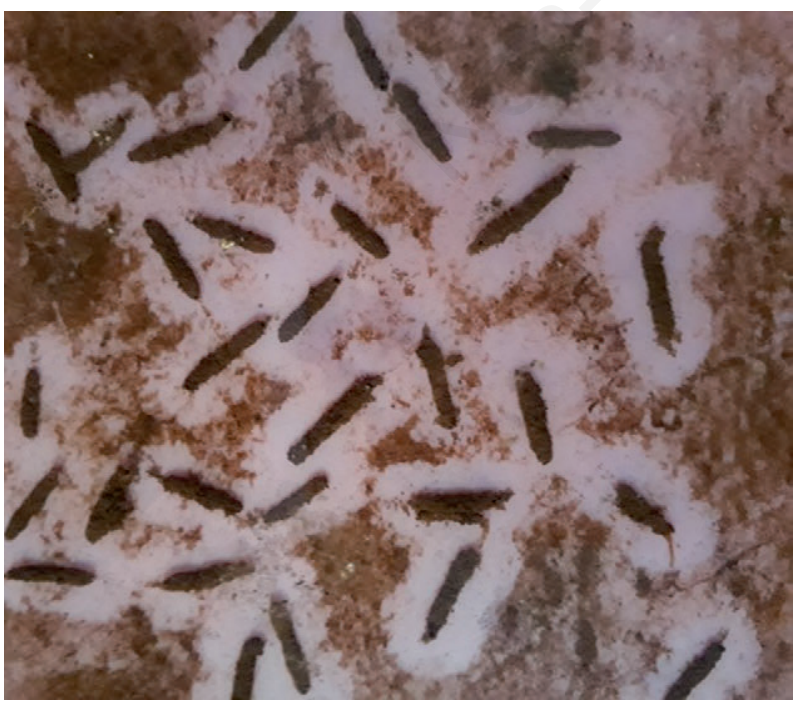

Fig. 1. Representative photograph showing the housing nests built by Chironomus ramosus larva using substratum material glued together with silk protein secretion to form cylindrical open-ended tubes (length $1.58 \pm 0.2 \mathrm{~cm}$ ).
Antarctic biomes (Kranzfelder and Ferrington, 2015). The life cycle of Chironomus comprises the egg, larva, pupa (aquatic stages) and adults (terrestrial) (Armitage et al., 1995; Nath et al., 2009). The midges form an abundant macroinvertebrate insect group of aquatic ecosystems and serve as food source for organisms in both aquatic and terrestrial habitats (Oliver, 1971). Chironomid midges are known to be extremely robust insects and recently, their impressive pliability to combat fluctuations in hydroperiodicity patterns have made them a popular model system for elucidating the consequences associated with climate change stressors such as temperaturehumidity imbalance (Walker et al., 1991; Larocque et al., 2001; Gusev et al., 2011; Cornette and Kikawada, 2011; Lee and Denlinger, 2015; Thorat and Nath, 2016; Thorat et al., 2017; Belle et al., 2017; Oppold et al., 2017).

\section{SILK PRODUCTION MACHINERY IN CHIRONOMUS}

\section{Salivary glands and Balbiani rings}

Chironomus larvae possess a pair of salivary glands (SGs) that are a type of acinar glands composed of $\sim 35$ 40 cells arranged in an oval fashion with a central gland lumen (Grossbach, 1977). In the case of C. ramosus, salivary glands possess $\sim 20-25$ cells (Fig. 2, personal observations). Larval SGs in Chironomus typically have a single layered 'flat' tissue-like appearance owing to their one-cell layer thickness. This offers a major advantage for handling ease and manipulation, thereby making them one of the most preferred model systems of differentiated insect tissues (Beermann, 1952). SG polytene chromosomes are amenable, especially for cytogenetic analysis and micromanipulations due to the high level of polytenization, which enables visualization of transcriptional activities at gene level (Thorat and Nath, 2013). Large puffs on midge polytene chromosome IV (arm G), referred to as Balbiani rings (BRs) (Fig. 3, representative data from our laboratory in C. ramosus) were later identified as sites of intensive transcription (Balbiani, 1881). Laufer and Nakase (1965) have shown that SG secretory processes appear to be closely linked with the activities of tissue-specific chromosomal puffs, particularly with the largest and prominent BRs. Furthermore, BR regions on polytene chromosomes have been demonstrated to contain genes encoding proteins which are the one of the major components of SG secretions. In fact, production of secretory proteins in Chironomus is governed by multigene family and apart from the genes located in the BRs, gene loci on other chromosomes are also crucial for the synthesis of silk proteins (Kao and Case, 1985, 1986; Case, 1986; Dreesen and Case, 1987; Dignam and Case, 1990). 
Secretory proteins (and other polysaccharides) synthesised in SGs are required for the overall growth and development, of which the silk proteins form an integral part (Grossbach, 1969). This secretion is initially stocked in the central lumen and depending on requirement, it is either utilized for bodily functions or is passed into the common gland duct from where it is carried to the salivarium and finally secreted out from the mouth for nest building activity (Churney, 1940; Case and Daneholt, 1978; Case and Wieslander, 1992). Thus, in principle, the housing nests are fibrous protein tubes spun underwater using the proteinaceous adhesives discharged from the glands (Grossbach, 1977; Case and Daneholt, 1997; Nath and Raut, 1998).

\section{Regulation and mechanism of silk extrusion}

The process of expulsion of silk proteins from SGs has been described in detail by Churney (1940). In brief, under the non-secretion state, two broad elastic bands block the aperture of the common gland canal by virtue of the cone-like plug they form within the canal. Secretion is facilitated with the displacement of the common canal (like a barrel) which is movable by retractor muscles attached to its dorsal surface, whereas, the elastic bands act as the piston. Pumping mechanism resulting from rapid contractions and retractions of the lateral walls of the common gland duct exerts a suction pressure on this apparatus. This stretches and separates the two elastic bands to open the aperture of the canal and force the secretion into the salivarium. Upon entry into the salivarium, the secretion then appears as an insoluble silklike thread. During the non-secretion phase, the retractor muscles relax and the elastic bands broaden and reinsert themselves within the aperture to close the secretion gate. Beermann (1961) confirmed that administration of pilocarpine can serve as an artificial method to trigger the secretory process by which the secretion could be completely emptied out from the glands. Alternately, atropine showed an opposite effect by blocking the delivery of secretion, plausibly by modulating the neuromusculatory transmissions (Pichon, 1974; Case and Wieslander, 1992). Physical factors such as tetanic shocks and chemical factors such as sodium ions have the ability to cause a considerable release of secretion from the glands. Potassium, calcium and magnesium ions, on the other hand, result in inhibition of the mechanism (Grossbach, 1977). In blood-feeding insects, nitrophorins, the salivary hemeproteins play a role for release of nitric oxide to bring about vasodilation and to reduce blood coagulation (Weber and Vinogradov, 2001). In the nonbiting midge, Chironomus, although the secretory process is also partly influenced by transport of hemal proteins (Doyle and Laufer, 1969); however, the role of other specific proteins (e.g. nitrophorin), have not yet been

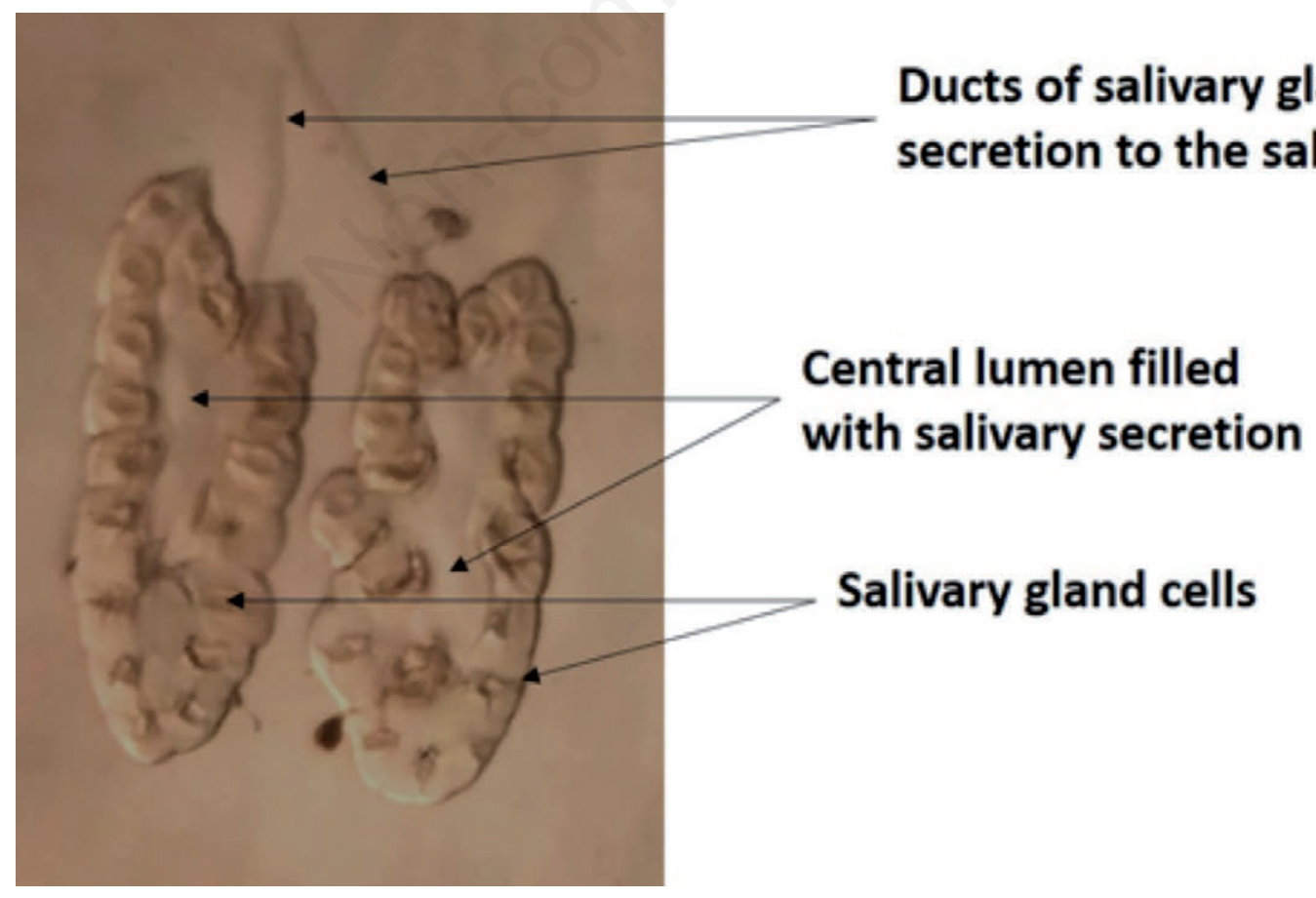

Fig. 2. Representative photomicrograph showing the larval salivary glands from Chironomus ramosus. Salivary gland of C. ramosus larva possesses 20-25 cells arranged in an oval fashion surrounding the central lumen where the secretion is stocked (magnification 40X). 
identified. It seems that nitrophorin, a protein with antihemostatic activity, has apparently got retained only in the biting midges (Diptera: Ceratopogonidae) (Langner et al. 2007) whereas, it probably disappeared down the evolutionary line in the non-biting midges (Diptera: Chironomidae) (unpublished proteomic data from authors' laboratory). Walshe (1951) has recorded interesting observations on larval behaviour inside the tube. The author noted that the larva extends its tube using the secretory threads to accommodate its growing size. Within the tube, larva shows a characteristic undulating movement that helps it draw water current across the tube for filter-feeding and gaseous exchange (Armitage et al., 1995; Nath and Gharpure, 2015). Meticulous observations by Walshe (1951) have further shown that inside the tube, the larva spins another funnel-shaped net along the anterior opening to capture detritus particles and planktonic organisms from the flowing stream of water. Furthermore, the author described that larval undulatory movements are interrupted by a short rest phase during which it engulfs the entire internal net along with the captured filtrate. Soon thereafter, it spins another fresh net and the cycle continues. These observations suggested not only the high rates of secretory protein synthesis in the salivary glands but also the importance of consistent maintenance of this state. Quantitative data have corroborated with these observations (Case and Wieslander, 1992). Emptied contents from fourth instar larval glands contained 7-12 $\mu \mathrm{g}$ protein (i.e. 0.175-0.3 $\mu \mathrm{g}$ protein per cell) and thus more than $50 \%$ of the protein content of a gland should be accounted for by secretory proteins. This remarkable bulk of secretory proteins can be freshly synthesized by the gland cells within $24 \mathrm{~h}$ and the overall rate of secretory protein synthesis can thus be

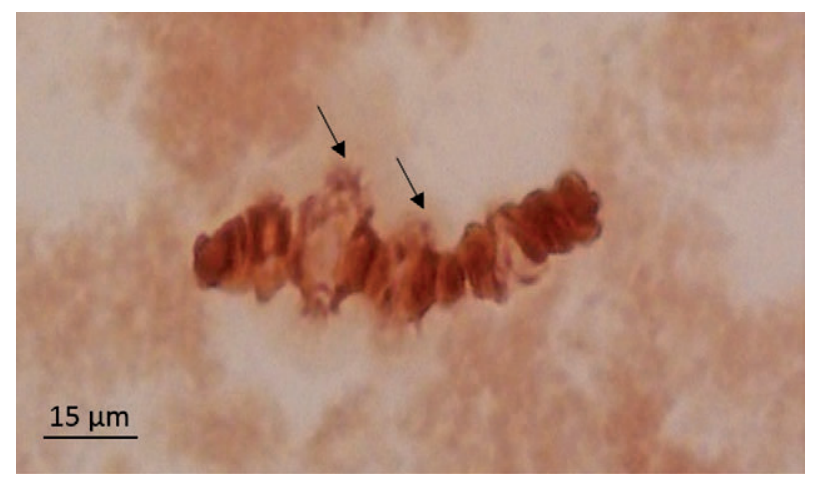

Fig. 3. Representative photomicrograph of chromosome IV (arm G) from salivary gland cells of Chironomus ramosus larva (acetocarmine staining) showing prominent Balbiani ring regions (indicated with arrows) (Nath and Godbole, 1997). estimated to be in the range of $0.2-0.3 \mu \mathrm{g}$ per cell/ $24 \mathrm{~h}$ (Case and Wieslander, 1992).

\section{Assembly of secretory proteins into silk}

Although microscopic examinations of the assembly of silk threads from Chironomus has been attempted (Grossbach, 1977; Dreesen et al., 1988), however, unlike other silk-producing organisms, a definitive and conclusive description of the assembling process is yet to be worked out. In vitro studies have shown that secretory proteins isolated from SG lumen appeared as web-like network of strands which coalesce into smooth fibrils and multistranded beaded fibres stabilized by electrostatic interactions and disulphide bonds (Wellman and Case, 1989). Based on this pilot attempt, a tentative hypothetical working model proposed by Case and Wieslander (1992) stated that the first step involves the conversion of secretory proteins $(18-1000 \mathrm{kDa})$ into smooth fibrils (5$20 \mathrm{~nm}$ ). The network of fibrils is then converted to multistranded, beaded fibres $(25-200 \mathrm{~nm})$, followed by the formation of parallel array of fibres (ø up to $400 \mathrm{~nm}$ ). Finally, this array of fibres gets transformed into a novel biopolymer as insoluble silk threads $(>1 \mu \mathrm{m})$. However, it must be noted that a concrete mechanism needs to be studied to reinforce this speculated pathway put forth by the authors.

\section{SALIVARY SECRETORY PROTEINS: NATURE AND COMPONENTS}

\section{Secretory proteins}

In Chironomus larvae, nomenclature of secretory proteins is based on their apparent molecular weight, for instance, sp160 and sp185 are secretory proteins with $\sim$ molecular weights 160 and $185 \mathrm{kDa}$ respectively (Rydlander and Edström, 1980a). According to Case and Wieslander (1992), these size values are only probabilistic and therefore the authors have suggested further validation using more precise tools and methods. Secretory protein profiles of $C$. tentans, $C$. pallidivittatus and C.riparius have shown the presence of different classes of proteins, ranging from large, intermediate and small size (Fig. 4). SpIs are the large size class, with an estimated molecular mass of $1000 \mathrm{kDa}$ which include spIa, spIb, spIc and spId (Rydlander et al., 1980b; Hertner et al., 1980; Hardy and Pelling, 1980). The intermediate size class contains secretory proteins from about 100 to $200 \mathrm{kDa}$ and include sps195, 185, 140 and 115. Finally, there appears the small size class $(\leq 100 \mathrm{kDa})$, which include sps65, 55, 40, 39, 38 and 18. In addition to these, special lobe cells of SG secrete ssp160, a protein not found in the other lobes (Beermann, 1952; Grossbach, 1969; Kolesnikov et al., 1981). 


\section{Large sized class secretory proteins}

As mentioned above, spIs (spIa, spIb, spIc and spId) fall under large size proteins with apparent molecular weights of about $1000 \mathrm{kDa}$. While $C$. tentans and $C$. pallidivittatus have been reported to possess all four spIs (spIa, spIb, spIc, and spId), C.riparius has shown to contain three spIs (Hertner et al., 1983; Serfling et al., 1983). All spIs are related in size and structure but are encoded by different genes. Notwithstanding their size, evidences have indicated that they possess monomeric nature. As highlighted by Case and Wieslander (1992) in the 1980s five laboratories in the world concurrently used gDNA and cDNA cloning to study the spI genes in $C$. tentans, $C$. pallidivittatus and $C$. riparius, which revealed that the primary structure of spIs as characteristic of fibrous proteins. They contain tandem copies of distinctive core repeats which are dominated by hydrophilic amino acids and conserved Cysteine (Cys) residues in most cases (Rydlander et al., 1980; Hertner et al., 1980, 1983; Rydlander, 1984; Hamodrakas and Kafatos, 1984; Kao and Case, 1985). Each core repeat contains 60-90 amino acids and possesses two domains: a constant $(\mathrm{C})$ region and a subrepeat (SR) region. Length of the C-region is typically 30 residues long (with 4 Cys,
1 Methione (Met), and 1 Phenyl alanine (Phe)), all of which are invariant. On the other hand, length of SR regions may be regular or variable due to the size and number of shorter repeated amino acid sequence elements. Core repeats are classified after amino acid sequence elements within their SR region. Elements within SR regions contain a tripeptide motif: basic residue-Pro-acidic residue in which basic residues are typically Arginine (Arg) or Lysine (Lys), while the acidic residues are Glutamine (Glu), phospho-serine or phosphothreionine (Hertner et al., 1983; Rydlander, 1984; Case and Wieslander 1992). The length of these repeating units generally decreases with a decrease in the size of the secretory protein. However, whether or not this pattern has any biological relevance is not understood. Based on these data, Hamodrakas and Kafatos (1984) attempted to predict their protein secondary structure and have provided very early predictive clues that they possess collagen-like structure.

\section{Intermediate sized class secretory proteins}

Similar to the large size class, intermediate size class of secretory proteins may contain a subfamily of structurally related proteins. Case et al. (1983a) and Case

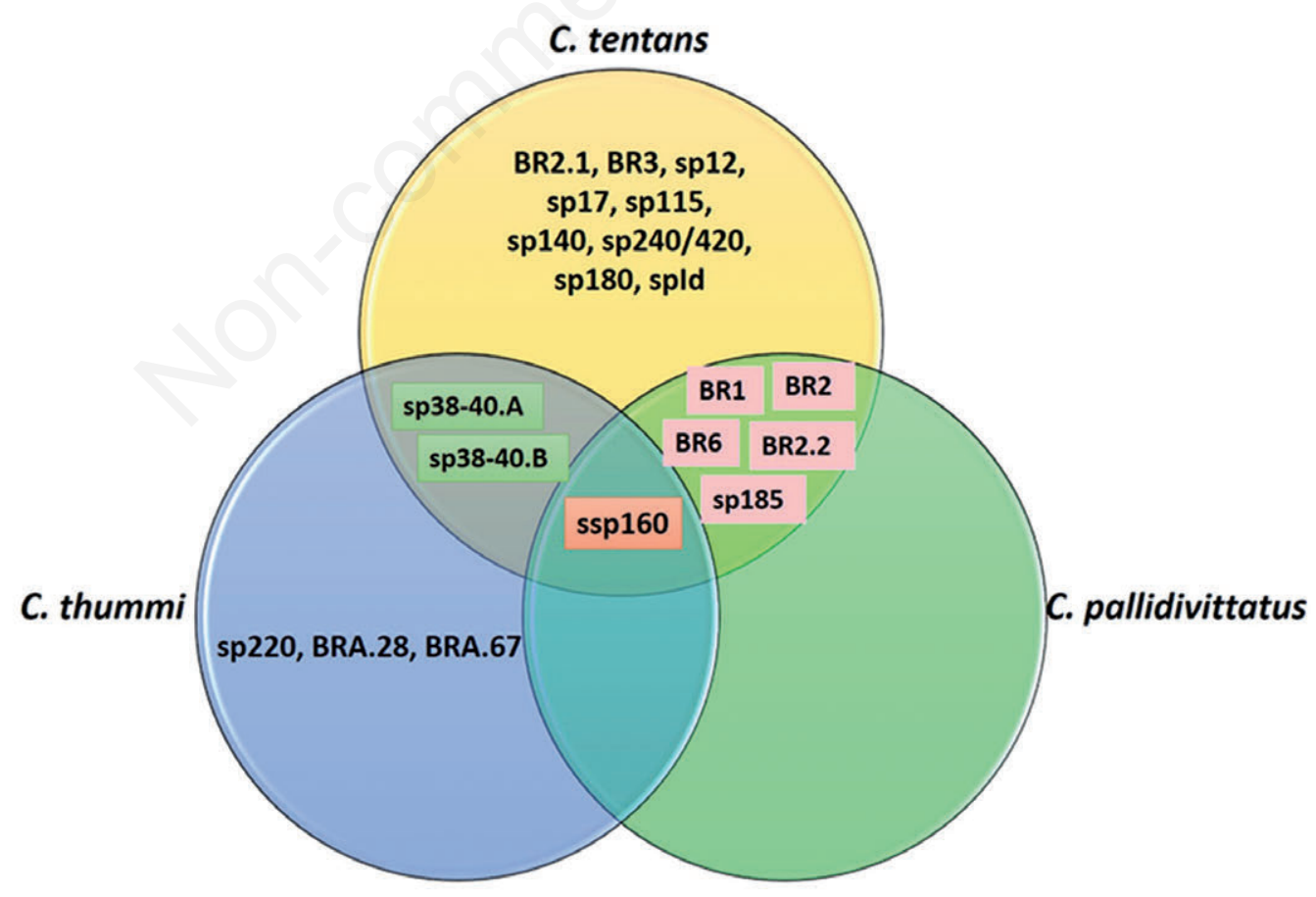

Fig. 4. Venn diagram constructed to illustrate the diversity and occurrence of silk proteins among the three well studied Chironomus species (C. tentans, C. pallidivittatus and C. thummi). ssp160 is found in all three species, sp38-40.A and sp38-40.B occurs in C. thummi and C. tentans while BR1, BR2, BR6, BR2.2 and sp185 is common to C. pallidivittatus and C. thummi. sp220, BRA.28 and BRA.67 is unique to $C$. thummi while BR2.1, BR3, sp12, sp17, sp115, sp140, sp240/420, sp180 and spId are unique to $C$. tentans. The diagram was compiled using the freely accessible information on silk proteins from Chironomus from UniProt database. 
and Byers (1983b) suggested that sp195 composed of about 50 tandemly arranged copies of a 25 -residue repeat. Furthermore, sp195 is hydrophilic in nature and shares features common to spIs. sp185 is coded by a gene in BR3 region (Dignam and Case, 1990; Paulsson et al., 1990). The predominant pattern of sp185 is 50-60 tandem copies of highly diverged repeats of hydrophilic amino acids. The most striking feature is that, similar to the C-region of spIs, it contains a motif of conserved Cys residues: Cys-X-Cys-Y-Cys approximately every 22-26 residues and also contain sporadic copies of the tripeptide motif. sp140 and sp115 possess a central portion containing 65 copies of a 14-residue repeat that is Lys and Glycine (Gly)-rich and composed of hydrophilic secretory proteins with most containing the tripeptide motif, a pattern similar to sub-repeats seen in spIs (Paulsson et al., 1990).

\section{Small sized class secretory proteins}

Evidences support the existence of structurally related subfamilies of secretory proteins among small size class proteins. The central portion of sp40 and sp38 contains six Cys residues whose spacing is similar to C-regions in spIs. In addition, they also contain several short tandem repeats containing Pro and hydrophilic residues.

Genes coding for spIs and those for sp195, sp185, sp140, sp115 and sp40 share common structural units. These genes either contain multiple repeats (sp195, sp185, $\mathrm{sp} 140$, and $\mathrm{sp} 115)$ or represent a prototype unit for core repeats (sp40). sp185 encoding gene contains repeats of conserved Cys codons similar to the $\mathrm{C}$-region of spI core repeats, whereas sp115 and sp140 encoding genes contain repeats of hydrophilic sequences along with the tripeptide motif as seen in the SR-regions of spIs. In the sp40 and sp195 genes, the repeats contain both conserved Cys codons and hydrophilic, Pro-rich regions. These structural similarities may likely be the possibility that these genes have originated from a common ancestor and that the regulation of expression of individual genes must have also evolved in parallel with the growing gene family (Hertner et al., 1983).

\section{FACTORS INFLUENCING EXPRESSION OF GENES ENCODING SECRETORY PROTEINS}

\section{Development}

Genes encoding spIs are expressed throughout the larval developmental phase with the relative level of each mRNA being highest during the second instar, the stage of rapid larval growth (Lendahl and Wieslander, 1987). On the other hand, variations in the relative levels of each spI and its mRNA are prominent in the fourth instar larvae (Case, 1986; Kao and Case, 1986; Dreesen et al., 1988). Expression of genes encoding intermediate and small size proteins has been examined only during stages within the fourth instar. sp185 is seen throughout the fourth instar while synthesis of sp195, sp140, sp40, and sp38 varies (Dignam and Case, 1990). Expression of sp40 gene reaches a high level during the first half of the fourth instar and subsequently begins to decline during the prepupal stages. In contrast, the expression of genes encoding sp195, sp140 and sp38 rises from negligible levels during the fourth instar to attain maximal levels at the prepupal stage (Dreesen et al., 1988; - Dignam and Case, 1990).

Based on the differential regulation of gene expression of secretory proteins, Dreesen et al. (1988) proposed two expression classes: 1) larval class genes expressed during all instars, encoding secretory proteins involved in formation of larval tubes; and 2) prepupal class genes encoding additional proteins essential for formation of prepupal silk required for ecdysis. Interestingly, in addition to specific intermediate and small size class secretory proteins, an spI is always present, indicative of its indispensable role in larval silk formation and tube building ability (Kao and Case, 1986). sp185, sp40 has been placed in the larval class while sp195, sp140 and sp38 belong to the prepupal class (Dreesen et al., 1988).

It has been well-established that hormones play a critical role in specific gene activities that in turn influence SG secretory products of Chironomus larvae. Clever and Karlson (1960) showed that ecdysone (insect molting hormone) could alter the activity of specific genes. The authors postulated this to be a result of normal developmental changes characteristic to metamorphosis. Subsequently, Lezzi and Gilbert (1969) demonstrated that external administration of ecdysone and juvenile hormone to $C$. tentans larvae had antagonistic effect on SG gene activities. While ecdysone stimulated specific gene activities in the form of chromosomal puffs, particularly the BR1, juvenile hormone, however, led to reduced BR1 activity but induced puff formation on chromosome I (region 19-A) which was observed to decline in activity post ecdysone treatment.

\section{Environmental change}

Synthesis of spIs is influenced by changes in environmental factors, for instance, change in chemical composition of the medium. Addition of galactose or glycerol to larval culture medium has shown to cause induction of BR6 puff on chromosome III along with an increase in transcription, synthesis and accumulation of spIc. Around the same time, BR2 puff size undergoes regression coupled with a halt in initiation of transcription of the spI genes contained in BR2, in which spId mRNA decays more rapidly than spIb mRNA (Galler et al., 1985; Case, 1986). The differential rate of decay of these mRNAs corresponds to the disappearance of their encoded proteins (Case, 1986; Lendahl and Wieslander, 
1987). Other compounds such as pilocarpine dimethylsulfoxide and environmental stressors such as heavy metal pollution, plasticizers such as butyl benzyl phthalate and temperature are known to modify the expression of genes in BRs (Sass, 1981; Meyer et al., 1983; Santa-Cruz et al., 1985; Michailovaa et al., 1998; Herrero et al. 2016). However, their effects on the synthesis of specific secretory proteins have not been examined.

\section{CONCLUSIONS AND FUTURE PERSPECTIVES}

As reviewed here, the salivary gland secretions of Chironomus contain silk proteins that occur in different sizes and are encoded by several genes. This silk has few unique features which can make it a suitable biopolymer for a variety of industrial and biomedical applications. In particular, its overall high cysteine makes it more resistant to various physical stresses and also amenable to chemical modifications. An added advantage is that, unlike few other silk-producing insects, Chironomus larvae need not be killed in order to extract the silk, given that the silk can be obtained in multiple rounds per larva throughout its larval life. However, the vast diversity in nature and composition of Chironomus silk is yet to be well understood before it can be considered for commercial applications. We thus hope that this review could serve as a crucible to arouse interest in this underexplored yet promising avenue of chironomid research.

\section{CONFLICT OF INTEREST}

The authors declare no conflict of interest.

\section{FUNDING}

LT is grateful for financial support received from the University Grants Commission- DSK-Postdoctoral Fellowship (UGC-DSK-PDF) and from DBT Bio-CARe Women Scientist Scheme, New Delhi, India. BBN and LT acknowledge partial funding received from DRDP, UGCCAS (Phase-III) and DST-PURSE grants to BBN.

\section{REFERENCES}

Aigner TB, DeSimone E, Scheibel T, 2018. Biomedical applications of recombinant silk-based materials. Adv. Mater. doi: org/10.1002/adma.201704636.

Andersson M, Johansson J, Rising A, 2016. Silk spinning in silkworms and spiders. Int. J. Mol. Sci. 17: 1290-1303.

Armitage P, Cranston PS, Pinder LCV, 1995. Chironomidae: Biology and ecology of non-biting midges. Chapman \& Hall, London.
Ashton NN, Pan H, Stewart RJ, 2016. Connecting caddisworm silk structure and mechanical properties: combined infrared spectroscopy and mechanical analysis. Open Biol. 6:160067. doi: org/10.1098/rsob.16006.

Balbiani EG, 1881. [Sur la structure du noyau des cellules salivaires chez les larves de Chironomus].[Article in French]. Zool. Anz. 4:637-641.

Belle S, Rius D, Bichet V, Massa C, Mavon C, Millet L, 2017. Combining limnology and paleolimnology to assess the influence of climate change on two lakes in Southern Greenland. Polar Biol. 40:1707-1719.

Beermann W, 1952. [Chromomerenkonstanz und spezifische Modifikationen der Chromosomenstruktur in der Entwicklung und Organdifferenzierung von Chironomus tentans].[Article in German]. Chromosoma 5:139-198.

Beermann W, 1961. [Ein Balbiani-Ring als Locus einer Speicheldrüsenmutation].[Article in German]. Chromosoma 12:1-25.

Case ST, Daneholt B, 1977. Cellular and molecular aspects of genetic expression in Chironomus tentans salivary glands, p. 45-77. In: Paul J (ed.), Biochemistry of cell differentiation. International review of biochemistry, vol 15 . University Park Press, Baltimore.

Case ST, Daneholt B, 1978. The size of the transcription unit in Balbiani ring 2 of Chironomus tentans as derived from analysis of the primary transcript and 75S RNA. J. Mol. Biol. 124:223-241.

Case ST, Summers RL, Jones AG, 1983a. A variant tandemly repeated nucleotide sequence in Balbiani ring 2 of Chironomus tentans. Cell 33:555-562.

Case ST, Byers MR, 1983b. Repeated nucleotide sequence arrays in Balbiani ring 1 of Chironomus tentans contains internally nonrepeating and subrepeating elements. J. Biol. Chem. 258:7793-7799.

Case ST, 1986. Correlated changes in steady-state levels of Balbiani ring mRNAs and secretory polypeptides in salivary glands of Chironomus tentans. Chromosoma 94 483-491.

Case ST, Wieslander L, 1992. Secretory proteins of Chironomus salivary glands: Structural motifs and assembly characteristics of a novel biopolymer, p. 187-226. In: S.T. Case (ed.), Results and problems in cell differentiation: Structure, cellular synthesis and assembly of biopolymers. Springer, Dordrecht.

Case ST, Powers J, Hamilton R, Burton MJ, 1994. Silk and silk proteins from two aquatic insects, p. 80-90. In: D. Kaplan, W.W. Adams, B. Farmer, C. Viney and D.C. Washington (eds.), Silk polymers: Materials science and biotechnology. ACS Symposium Series.

Churney L, 1940. A contribution to the anatomy and physiology of the salivary gland system in the larva of Chironomus (diptera). J. Morphol. 66: 391-407.

Clever U, Karlson P, 1960. [Induktion von puff-veränderungen in den speicheldrüsenchromosomen von Chironomus tentans durch Ecdyson].[Article in German]. Exptl. Cell Res. 20:623-626.

Cornette R, Kikawada T, 2011. The induction of anhydrobiosis in the sleeping chironomid: Current status of our knowledge. IUBMB Life 63:419-429.

Craig CL, 1997. Evolution of arthropod silks. Ann. Rev. Entomol. 42:231-67. 
Doyle D, Laufer H, 1969. Sources of larval salivary gland secretion in the dipteran Chironomus tentans. J. Cell Biol. 40:61-78.

Dreesen TD, Case ST, 1987. A peptide-reactive antibody to a Balbiani ring gene product: immunological evidence that a 6.5-kb RNA in Chironomus tentans salivary glands is mRNA for a $180-\mathrm{kDa}$ non-fibrous component of larval secretion. Gene 55:55-65.

Dreesen TD, Lezzi M, Case ST, 1988. Developmentally regulated expression of a Balbiani ring 1 gene for a $180-\mathrm{kD}$ secretory polypeptide in Chironomus tentans salivary glands before larval/pupal ecdysis. J. Cell Biol. 106:21-27.

Dignam SS, Case ST, 1990. Balbiani ring 3 in Chironomus tentans encodes a $185-\mathrm{kDa}$ secretory protein which is synthesized throughout the fourth larval instar. Gene 88:33140.

Flammang P, Santos R, 2015. Biological adhesives: from biology to biomimetics. Interface Focus 5:20140086. doi: org/10.1098/rsfs.2014.0086.

Forooshani KP, Lee BP, 2017. Recent approaches in designing bioadhesive materials inspired by mussel adhesive protein. J. Polym. Sci. Part A: Polym. Chem. 55:9-33.

Galler R, Saiga H, Widmer RM, Lezzi M, Edström J-E, 1985. Two genes in Balbiani ring 2 with metabolically different 75S transcripts. EMBO J. 4:2977-2982.

Graham LD, 2008. Biological adhesives from nature, p. 236253. In: G. Wnek and G. Bowlin (eds.), Encyclopedia of biomaterials and biomedical engineering. Informa Healthcare, New York \& London.

Grossbach U, 1969. [Chromosomen-Aktivität und biochemische Zelldifferenzierung in del Speicheldrüsen von Camptochironomus].[Article in German]. Chromosoma 28: 36-244.

Grossbach U, 1977. The salivary gland of Chironomus (Diptera): A model system for the study of cell differentiation, p. 147-196. In: W. Beermann (ed.) Biochemical differentiation in insect glands: Results and problems in cell differentiation. Springer, Dordrecht.

Gusev O, Cornette R, Kikawada T, Okuda T, 2011. Expression of heat shock protein-coding genes associated with anhydrobiosis in an African chironomid Polypedilum vanderplanki. Cell Stress Chaperones 16:81-90.

Hardy PA, Pelling C, 1980. Cell-free synthesis and immunological characterization of salivary proteins from Chironomus tentans. Chromosoma 81:403-417.

Hardy JG, Römer, Scheibel TR, 2008. Polymeric materials based on silk proteins. Polymer 49:4309-4327.

Herrero Ó, Planelló R, Morcillo G, 2016. The ribosome biogenesis pathway as an early target of benzyl butyl phthalate (BBP) toxicity in Chironomus riparius larvae. Chemosphere 144:1874-84.

Hertner T, Meyer B, Eppenberger HM, Mahr R, 1980. The secretion proteins in Chironomus tentans salivary glands: electrophoretic characterization and molecular weight estimation. Wilhelm Roux's Arch. Dev. Biol. 189:69-72.

Hertner T, Eppenberger HM, Lezzi M, 1983. The giant secretory proteins of Chironomus tentans salivary glands: the organization of their primary structure, their amino acid and carbohydrate composition. Chromosoma 88:194-200.

Hamodrakas SJ, Kafatos FC, 1984. Structural implications of primary sequences from a family of Balbiani ring-encoded proteins in Chironomus. J. Mol. Evol. 20:296-303.

Jin HJ, Kaplan DL, 2003. Mechanism of silk processing in insects and spiders. Nature 424:1057-1061.

Kao WY, Case ST, 1985. A novel giant secretion polypeptide in Chironomus salivary glands: implications for another Balbiani ring gene. J. Cell Biol. 101:1044-1051.

Kao WY, Case ST, 1986. Individual variations in the content of giant secretory polypeptides in salivary glands of Chironomus. Chromosoma 94:475-482.

Kolesnikov NN, Karakin EI, Sebeleva TE, Meyer L, Serfling E, 1981. Cell-specific synthesis and glycosylation of secretory proteins in larval salivary glands of Chironomus thummi. Chromosoma 83:661-677.

Kranzfelder P, Ferrington LC Jr, 2015. Characterization of Chironomidae (Diptera) surface-floating pupal exuviae sample sort time from coastal tropical aquatic systems. Environ. Monit. Assess.187:70. doi: org/10.1007/s10661015-4313-0.

Langner KF, Darpel KE, Denison E, Drolet BS, Leibold W, Mellor PS, Mertens PP, Nimtz M, Greiser-Wilke I, 2007. Collection and analysis of salivary proteins from the biting midge Culicoides nubeculosus (Diptera: Ceratopogonidae). J. Med. Entomol.44:238-48.

Larocque I, Hall RI, Grahn E, 2001. Chironomids as indicators of climate change: a 100-lake training set from a subarctic region of northern Sweden (Lapland). J. Paleolimnol. 26:307-322.

Laufer H, Nakase Y, 1965. Salivary gland secretion and its relation to chromosomal puffing in the dipteran, Chironomus thummi. P. Natl. Acad. Sci. USA 53:511-516.

Lee RE Jr, Denlinger DL, 2015. Stress tolerance in a polyextremophile: the southernmost insect. Can. J. Zool. 93:679-686.

Lendahl U, Wieslander L, 1987. Balbiani ring (BR) genes exhibit different patterns of expression during development. Dev. Biol. 121:130-138.

Lezzi M, Gilbert L, 1969. Control of gene activities in the polytene chromosomes of Chironomus tentans by ecdysone and juvenile hormone. P. Natl. Acad. Sci. USA 64:498-503.

Meyer B, Mahr R, Eppenberger HM, Lezzi M, 1983. The activity of Balbiani rings land 2 in salivary glands of Chironomus tentans larvae under different modes of development and after pilocarpine treatment. Dev. Biol. 98:265-277.

Michailovaa P, Petrovab B, Sellac G, Ramellac L, Boveroc S, 1998. Structural-functional rearrangements in chromosome $\mathrm{G}$ in Chironomus riparius (Diptera, Chironomidae) collected from a heavy metal-polluted area near Turin, Italy. Environ Poll. 103:127-134.

Naik DG, Babrekar AA, Nath BB, 2006. 'Pheromone-like' compounds in the cuticle of aquatic Chironomus larva. Chem. Ecol. 22:501-508.

Nath BB, Godbole NN, 1997. Chromosomal characterization of a tropical midge. Cytobios 91:25-31.

Nath BB, Godbole NN, 1998. Technique for mass rearing of Indian Chironomus species (Diptera, Nematocera, Chironomidae). Studia Dipterologica 5:187-193.

Nath BB, Raut N, 1998. Behavioural studies on "tuberecognition ability" of Chironomus larvae. Ind. J. Exptal. Biol. 36:826-828. 
Nath BB, Thorat L, Babrekar A, Datkhile K, Ghadge A, Gaikwad R, Meshram DC, 2009. Development of a new design of an insectary model and environmental assessment studies on chironomid midges. Chironomus 22:1-13.

Nath BB, Gharpure DC, 2015. A novel computational approach of image analysis to quantify behavioural response to heat shock in Chironomus ramosus larvae (diptera: chironomidae). Eur. J. Envtl. Sci. 5:57-61.

Ohkawa K, Nomura T, Arai R, Abe K, Tsukada M, Hirabayashi $\mathrm{K}, 2014$. Characterization of underwater silk proteins from Caddisfly Larva, Stenopsyche marmorata, p. 107-122. In: T. Asakura and T. Miller (eds.) Biotechnology of silk, biologically inspired systems. Springer, Dordrecht.

Oliver DR, 1971. Life history of Chironomidae. Ann. Rev. Entomol. 16: 1-230.

Oppold A-M, Wieser A, Schell T, Patel S, Schmidt H, Hankeln T, Feldmeyer B, Pfenninger M, 2017. The genomic footprint of climate adaptation in Chironomus riparius. bioRxiv 14:45-80

Paulsson G, Lendahl U, Galli J, Ericsson C, Wieslander L, 1990. The Balbiani ring 3 gene in Chironomus tentans has a diverged repetitive structure split by many introns. Mol. Biol. 211:331-349.

Pichon Y, 1974. The pharmacology of the insect nervous system, pp. 102-174. In: M. Rockstein (ed.), The physiology of insecta. Academic Press, New York.

Rydlander L, Edström J-E, 1980a. Large sized nascent protein as dominating component during protein synthesis in Chironomus salivary glands. Chromosoma 81:85-99.

Rydlander L, Pigon A, Edström J-E, 1980b. Sequences translated by Balbiani ring 75S RNA in vitro are present in giant secretory protein from Chironomus tentans. Chromosoma 81:101-113.

Rydlander L, 1984. Isolation and characterization of the two giant secretory proteins in salivary glands of Chironomus tentans. Biochem. J. 220:423-431.

Sass H, 1981. Effects of DM SO on the structure and function of polytene chromosomes of Chironomus. Chromosoma 83: 19-643.

Santa-Cruz MS, Morcillo G, Diez JL, 1985. Ultrastructure of a temperature-induced Balbiani ring in Chironomus thummi. 52:205-211.

Sehnal F, Akai H, 1990. Insect silk glands: their types, development and function, and effects of environmental factors and morphogenetic hormones on them. Int. J. Insect Morphol. Embryol. 19:79-132.

Sehnal F, Sutherland T, 2008. Silks produced by insect labial glands. Prion 2:145-153.

Serfling E, Meyer L, Rudolph A, Steiner K, 1983. Secretory proteins and Balbiani ring gene activities in salivary glands of Chironomus thummi larvae. Chromosoma 88:16-23.

Smith AM, 2016. Biological adhesives. Springer, Berlin.

Sone ED, 2016. Interfacial phenomena in marine and freshwater mussel adhesion, p. 129-151. In: A.M. Smith (ed.), Biological adhesives. Springer, Berlin.
Stewart RJ, Wang CS, 2010. Adaptation of caddisfly larval silks to aquatic habitats by phosphorylation of $\mathrm{H}$-fibroin serines. Biomacromol. 11:969-974.

Sutherland TD, Campbell PM, Weisman S, Trueman HE, Sriskantha A, Wanjura WJ, Haritos VS, 2006. A highly divergent gene cluster in honeybees encodes a novel silk family. Genome Res. 16:1414-21.

Sutherland TD, Young JH, Weisman S, Hayashi CY, Merritt DJ, 2010. Insect silk: One name, many materials. Annu. Rev. Entomol. 55:171-88.

Sutherland TD, Church JS, Hu X, Huson MG, Kaplan DL, Weisman S. 2011. Single honeybee silk protein mimics properties of multi-protein silk. PLoS One 6:e16489.

Thorat L, Nath BB, 2013. Chironomid midges: a forgotten model of developmental research. Acta Zoologica 94:249-253.

Thorat L, Nath BB, 2015. Tolerance to desiccation stress in Chironomus ramosus plasticity in homeostatic control. Eur. J. Environm. Sci. 5:86-91.

Thorat L, Nath BB, 2016. Quantitative assessment of larval desiccation tolerance in Oriental Chironomus species. Curr. Sci. 11:1448-1449.

Thorat L, Oulkar D, Banerjee K, Gaikwad S, Nath BB, 2017. High-throughput mass spectrometry analysis revealed a role for glucosamine in potentiating recovery following desiccation stress in Chironomus. Sci. Rep. 7: 659-3671.

Tsukada M, Khan MM, Inoue E, Kimura G, Hun JY, Mishima M, Hirabayashi K, 2010. Physical properties and structure of aquatic silk fiber from Stenopsyche marmorata. Int. J. Biol. Macromol. 46 54-58.

Walker IR, Smol JP, Engstrom DR, Birks HJB, 1991. An assessment of Chironomidae as quantitative indicators of past climatic change. Can. J. Fish. Aquat. Sci. 48:975-987.

Walker AA, Weisman S, Church JS, Merritt DJ, Mudie ST, Sutherland TD, 2012. Silk from Crickets: A New Twist on Spinning. PLoS One 7: e30408.

Walshe BM, 1951. The feeding habits of certain chironomid larvae (subfamily Tendipedinae). Proc. Zool. Soc. Lond 121:63-79.

Watanabe M, Kikawada T, Fujita A, Forczek E, Adati T, Okuda T, 2004. Physiological traits of invertebrates entering cryptobiosis in a postembryonic stage. Eur. J. Entomol. 101: 39-444.

Watanabe M, 2006. Anhydrobiosis in invertebrates. App. Entomol. Zool. 41:15-3.

Weber RE, Vinogradov SN, 2001. Nonvertebrate hemoglobins: Functions and molecular adaptations. Physiol. Rev. 81: 569-628.

Weisman S, Trueman HE, Mudie ST, Church JS, Sutherland TD, Haritos VS, 2008. An unlikely silk: the composite material of green lacewing cocoons. Biomacromol. 9:3065-3069.

Wellman SE, Case ST, 1989. Disassembly and reassembly in vitro of complexes of secretory proteins from Chironomus tentans salivary glands. J. Biol. Chem. 264:10878-10883.

Yonemura N, Sehnal F, Mita K, Tamura T, 2006. Protein composition of silk filaments spun under water by caddisfly larvae. Biomacromol. 7:3370-3378. 